\title{
Characteristics of Selected Waste-To-Energy Technologies and Suitability for Oman
}

\author{
Wajeeha A. Qazi ${ }^{\mathrm{a}}$, Mohammed F.M. Abushammala ${ }^{\mathrm{a}}$
}

\begin{abstract}
The fast economic development and urbanization caused rapid increase of waste generation worldwide. Oman produced 1.5 million tons of municipal solid waste (MSW) in 2012 which is expected to elevate to 1.89 million tons in 2030. This rapid increase needs to be tackled to reduce the generation rates along with the environmental impacts it imposes. Currently in Oman other than recycling there are no treatment facilities, and therefore dumping waste into the landfill is the only and ultimate way to dispose solid waste. Thus this research aims present the process and specific aspects of Waste-To-Energy (WTE) technologies and determine the suitable technology for Oman depending on its waste composition and characteristics. In conclusion, the waste characteristics shows the potential to set up a WTE technology in Oman which will help to reduce the amount of waste, greenhouse gas emissions, developing and maintaining costs of landfills, and tackle the issue of portable water by using the produced energy for seawater desalination.
\end{abstract}

Keywords: biochemical; technologies; feedstock; thermal technologies; waste-to-energy; waste management

\section{Introduction}

The generation of waste has rapidly increased worldwide owing to the fast-economic development and urbanization. In GCC, Oman has made the most rapid progress in the development within a short period of time (M. Samah, 2011). Oman produced 1.5 million tons of municipal solid waste (MSW) in 2012 which is expected to elevate to 1.89 million tons in 2030 Be'ah (2016), This rapid increase in waste generation rates is a challenging issue for the Sultan of Oman because of the limited land availability, and increased greenhouse gas emissions owing to the disposal of majority of MSW to 350 authorized and unauthorized dumpsites (Zafar, 2016). Oman's current waste management system is struggling to handle the growing amounts of waste and this issue is difficult to be resolved if Oman purely focuses on waste disposal. Therefore the current situation urgently requires to improve waste prevention, set up MSW energy recovery plants for the reduction of mass and volume of waste, and to alleviate health hazards from pollution. In Europe for thermal and electricity generation around 40 million tons of MSW is incinerated yearly, whereas worldwide 130 million tons of MSW is combusted annually (J. Nixon, 2013). Oman's primary energy consumption mix consist of natural gas $(97.5 \%)$ and diesel $(2.5 \%)$. The zero renewable energy contribution and heavy reliance on fossil fuels could lead to the loss of natural resources in future (I.Velghe, 2011). The composition of MSW in Oman involves $27 \%$ food waste, followed by $21 \%$ plastic, $10 \%$ carton, $6 \%$ glass, $6 \%$ textile, $5 \%$ park and bio waste, $5 \%$ paper, $2 \%$ wood with the moisture content of $30 \%$ and average energy content of $10 \mathrm{MJ} / \mathrm{kg}(\mathrm{Al}-$ Harrasi, H., Personal Communication, Dec 7, 2016), Be'ah (2016), . The average energy content of waste in Oman shows the potential of energy recovery. There are many established and emerging thermal Waste-to-Energy (WTE) technologies. The thermal WTE technologies include incineration, gasification, pyrolysis and hydrothermal carbonization (HTC) C. He, A. Giannis, and J.Y. Wang. (2013), C. Tatarniuk (2007), C. Ducharme (2010), . Each WTE technology process specific quality (composition and characteristics) and quantity of waste. Thus, for proposing a suitable waste management plan or technology for a particular place requires to consider its waste composition, characteristics and generation rates (A.S.Khan, 2011), C. Tatarniuk (2007), (M. Ouadi, 2013).

\section{Waste to Energy Technologies}

\section{A. Incineration Technology}

Method: Thermochemical (R. Atwadkar, 2014).

Principle of Process: Conversion by complete oxidation (R. Atwadkar, 2014).

Reaction Type: Exothermic (R. Atwadkar, 2014).

Typical Waste Treating Capacity: 50,000 - 750,000 tons/year H. Chiu et al (2016).

Feedstock Requirements: Biological and Synthetic origin dry wastes (R. Atwadkar, 2014).

Preprocessing Method of Feedstock: Drying and Pelletization (R. Atwadkar, 2014), [27].

Permitted Moisture Content of Feedstock: 25 - $30 \%$ (R. Atwadkar, 2014).Residence Time: Seconds - Minutes

Catalyst: Non-catalytic (R. Atwadkar, 2014).Products: Heat \& Ash (R. Atwadkar, 2014), D. Wong, and S. Tam(2014),.

Environmental Issues: Ash discharge and Toxic gases ( $R$. Atwadkar, 2014).

Cost (Capital \& O \& M): Medium - High (R. Atwadkar, 2014).

Efficiency (\%): 50 - $60 \%$ (R. Atwadkar, 2014).

Product Applications: Heat and Power applications, Aggregate and filler material. (R. Atwadkar, 2014), U. Arena (2016.)Future Potential: Moderate Potential (R. Atwadkar, 2014). Gasification is a thermochemical way of transferring organic material (biomass or MSW) into other forms of energy through a chemical reaction instead of burning. It involves the conversion of liquid and solid materials into clean and useful syngas (S. Narnaware, 2016), Gasification Technologies Council (GTC) (2014.), (N. Berge, 2015). The specifications of gasification technology are as follow: 
Method: Thermochemical (R. Atwadkar, 2014).

Principle of Process: Conversion by complete oxidation (R. Atwadkar, 2014).

Reaction Type: Exothermic (R. Atwadkar, 2014).

Typical Waste Treating Capacity: 50,000 - 750,000 tons/year H. Chiu et al (2016)., .

Feedstock Requirements: Biological and Synthetic origin dry wastes (R. Atwadkar, 2014).

Preprocessing Method of Feedstock: Drying and Pelletization (R. Atwadkar, 2014), [27].

Method: Thermochemical (J. Libra et al., 2011).

Principle of Process: Thermal degradation in the absence of oxygen (A.Bosmans, 2013).

Reaction Type: Endothermic B. Basak. (2016.),.

Typical Waste Treating Capacity: 10 - 100 tons/day

Feedstock Requirements: Dry mixed MSW without inorganic materials

Preprocessing Method of Feedstock: Shredding and drying (F. $\mathrm{Ni}, 2014)$.

Permitted Moisture Content of Feedstock: Below 20\% D.O. Onyango, and J.W. Kaluli(2016),

Temperature $\left({ }^{\circ} \mathrm{C}\right): 400-900{ }^{\circ} \mathrm{C}$ (Stantec, 2011).

Residence Time: Slow pyrolysis (Hours - Weeks), Flash pyrolysis $(10-20 \mathrm{sec})$ and Fast pyrolysis $(1 \mathrm{sec})$.

Permitted Moisture Content of Feedstock: $25-30 \%$ (R. Atwadkar, 2014).

Residence Time: Seconds - Minutes

Catalyst: Non-catalytic (R. Atwadkar, 2014).

Products: Heat \& Ash (R. Atwadkar, 2014), D. Wong, and S. Tam (2014),

Environmental Issues: Ash discharge and Toxic gases (R. Atwadkar, 2014).

Cost (Capital \& O \& M): Medium - High (R. Atwadkar, 2014).

Efficiency (\%): 50 - $60 \%$ (R. Atwadkar, 2014).Product Applications: Heat and Power applications, Aggregate and filler material. (R. Atwadkar, 2014), U. Arena (2016.), .

Future Potential: Moderate Potential (R. Atwadkar, 2014).

Method: Thermochemical (R. Atwadkar, 2014).Principle of Process: Conversion by partial oxidation (R. Atwadkar, 2014), (K. Warren et al., 2013).Reaction Type: Endothermic/Exothermic (R. Atwadkar, 2014), (F. Ni, 2014).Typical Waste Treating Capacity: 250 - 500 tons/day Gasification Technologies Council (GTC) (2014.), Feedstock Requirements: Dry mixed MSW without inorganic materials. (R. Atwadkar, 2014).Preprocessing Method of Feedstock: Shredding and drying (R. Atwadkar, 2014), (J. Libra et al., 2011).Permitted Moisture Content of Feedstock: Below 15\% (R. Atwadkar, 2014), (K. Warren et al., 2013). Temperature $\left({ }^{\circ} \mathrm{C}\right): 500-1300{ }^{\circ} \mathrm{C}$ (R. Atwadkar, 2014), (Environment, Ricardo Energy \&"Thermal treatment", , 2016).Residence Time: $10-20 \mathrm{sec}$ (R. Atwadkar, 2014)

Catalyst: Non-catalytic (R. Atwadkar, 2014).
Products: Syngas and char (R. Atwadkar, 2014), (S. Narnaware, 2016).NCV (net calorific value) of Syngas: $4-10 \mathrm{MJ} / \mathrm{Nm}^{3}$ (by using Air), $10-15 \mathrm{MJ} / \mathrm{Nm}^{3}$ (by using Oxygen) (R. Atwadkar, 2014), (Environment, Ricardo Energy \& "Thermal treatment", , 2016).Environmental Issues: Organic compound emission, Generation of char and Toxic gases (R. Atwadkar, 2014).

Cost (Capital \& O \& M): High (R. Atwadkar, 2014).

Efficiency (\%):70 - $80 \%$ (R. Atwadkar, 2014).

Product Applications: Transport fuel, Power and heat application, Fertilizers and chemicals (R. Atwadkar, 2014), U. Arena (2016.), .

Future Potential: High Potential (R. Atwadkar, 2014), (N. Berge, 2015).

\section{B. Pyrolysis Technology}

Pyrolysis converts carbonaceous materials in to syngas (mixture of $\mathrm{CO}, \mathrm{H}_{2}, \mathrm{CO}_{2}$ and $\mathrm{CH}_{4}$ ), mixture of solids (Char) and liquids (Oxygenated oils) by thermochemical decomposition in the absence of oxygen or other reagent H. Raclavska, A. Corsaro, A. Hlavsova, D. Juchelkova, and O. Zajonc (2015), ,[19], ("Gasification: The waste and energy solution", 2011). Pyrolysis has three types of reaction depending on the temperature and residence time of the feedstock, named as slow, flash and fast pyrolysis. Slow pyrolysis (conventional pyrolysis) involves low heating rates of feedstock $\left(0.1-2{ }^{\circ} \mathrm{C} / \mathrm{sec}\right)$, low residence time ( $\mathrm{sec}$ - few days) and low temperature (about $500^{\circ} \mathrm{C}$ ), with the main products formed are char and tar. Whereas, the flash pyrolysis operates at moderate temperate $\left(400-600^{\circ} \mathrm{C}\right)$, heating rates above $2^{\circ} \mathrm{C} / \mathrm{Sec}$ and less than $2 \mathrm{sec}$ of residence time, with the key products formed are tar and biooil. Fast pyrolysis (thermolysis) involves temperatures above $550^{\circ} \mathrm{C}$, high heating rates of $200-10^{5}{ }^{\circ} \mathrm{C} / \mathrm{sec}$ and very short residence time, with the quality products being formed (gases rich in ethylene) which can be used for the production of alcohols/gasoline. Mostly fast pyrolysis is used for practical applications due to the nature of its products which is much closer to fossil fuels currently used D.O. Onyango, and J.W. Kaluli(2016), , A.J. Marshall (2013),. The specifications of pyrolysis technology are as follows:

Method: Thermochemical (J. Libra et al., 2011).

Principle of Process: Thermal degradation in the absence of oxygen A.S.Khan. (2011).

Reaction Type: Endothermic $\quad$ B. Basak. (2016.),

Typical Waste Treating Capacity: 10 - 100 tons/day

Feedstock Requirements: Dry mixed MSW without inorganic materials Preprocessing Method of Feedstock: Shredding and drying (F. Ni, 2014).Permitted Moisture Content of Feedstock: Below 20\% D.O. Onyango, and J.W. Kaluli (2016), . Temperature $\left({ }^{\circ} \mathrm{C}\right): 400-900{ }^{\circ} \mathrm{C}$ (Stantec, 2011).Residence Time: Slow pyrolysis (Hours - Weeks), Flash pyrolysis (10 $20 \mathrm{sec}$ ) and Fast pyrolysis (1 sec).Products: Syngas, Oxygenated oils and Char.NCV (net calorific value) of Syngas: $10-20 \mathrm{MJ} / \mathrm{Nm}^{3}$ C. Tatarniuk (2007). Environmental Issues: Inorganic compound emission, inert mineral ash, toxic gases and unreformed carbon. (Environment, Ricardo Energy \& "Thermal treatment", 2016). 
Future Potential: High Potential (J. Libra et al., 2011).

\section{Hydrothermal Carbonization Technology}

HTC is a thermochemical process which in the presence of water converts the organic substances to hydro char under moderate pressure $(2-10 \mathrm{MPa})$ and temperature $\left(180-350^{\circ} \mathrm{C}\right)$. The hydro char produced exhibit mesoporous textures, high aromaticity structures and moderate calorific value C. He, A. Giannis, and J.Y. Wang. (2013), This process passes the feedstock through sequence of reactions, which includes hydrolysis, dehydration, decarboxylation, aromatization and condensation resulting in the formation of products in gas, liquid and solid (hydro char) states (X. Lu, 2014). The specifications of HTC technology are as follows [19], (X. Lu, 2014), (Council, 2000), C. He, A. Giannis, and J.Y. Wang. (2013):

Principle of Process: Conversion by hot water process.

Typical Waste Treating Capacity: Scalable.

Feedstock Requirements: Wet mixed organic waste.

Preprocessing Method of Feedstock: Shredding and wetting.

Temperature $\left({ }^{\circ} \mathrm{C}\right): 180-350{ }^{\circ} \mathrm{C}$.

Residence Time: $1-12$ hour.

Products: Hydro char, Organic compounds (water soluble) and Energy rich gases.

Environmental Issues: Toxic emissions.

Cost (Capital \& O \& M): High.

Efficiency (\%): Carbon Efficiency (90\%) and Energy Efficiency (70\%).

Product Applications: Soil augmentation, Environmental remediation, Alternative energy source and Fuel source.

Future Potential: High Potential.

\section{Waste Quality and quantity in Oman}

The composition, characteristics and generation of waste is an important factor which must be considered to select the suitable WTE technology for Oman A.Bosmans, I. (2013)., C. Tatarniuk (2007), (M. Samah, 2011). According to the 'Ramboll Waste Survey' moisture content of waste in Oman is around 30\% (AlHarrasi, H., Personal Communication, and Dec 7, 2016). The organic fraction of waste in Oman is $71.20 \%$ and $65.80 \%$ of the total MSW in winter and summer respectively. Whereas, the inorganic fraction accounts for $28.80 \%$ and $34.02 \%$ in winter and summer respectively T. Palanivel, and H. Sulaiman (2014), . The generation rates of waste in Oman are given in Fig. 1. The results showed the increasing trend of waste generation with the increase in population over the years. The waste generation correlated positively with the population, whereas when the population is increased, the higher waste generated. Whereas, the composition of MSW in
Oman is involves $27 \%$ food waste, followed by $21 \%$ plastic, $10 \%$ carton, $6 \%$ glass, $6 \%$ textile, $5 \%$ park and bio waste, $5 \%$ paper, $2 \%$ wood with the moisture content of $30 \%$ and average energy content of $10 \mathrm{MJ} / \mathrm{kg}$ (Fig. 2), (Al-Harrasi, H., Personal Communication, Dec 7, 2016), Be'ah (2016), .

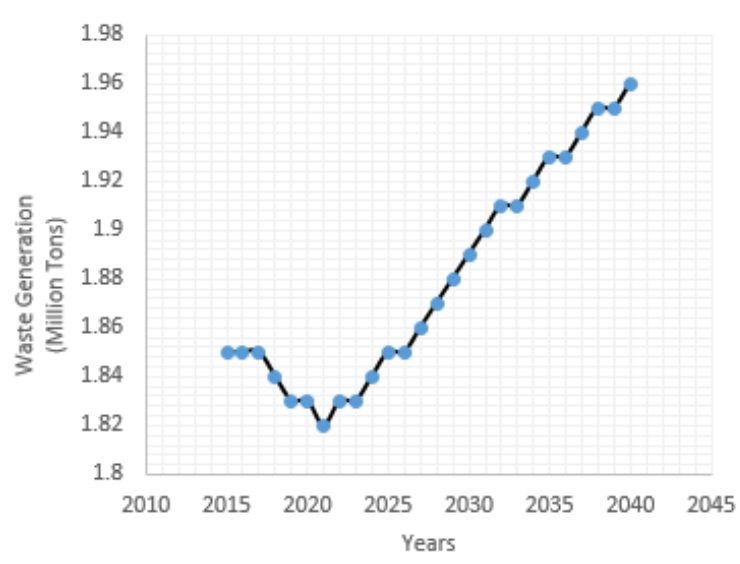

Fig. 1. Waste generation rates in Oman from 2016 - 2040 B. Basak. (2016.),

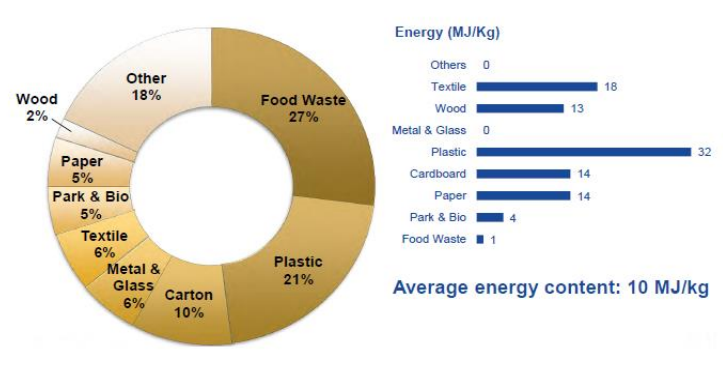

Fig. 1. Waste characteristics and composition in Oman Be'ah (2016),

\section{Discussion and conclusion}

This paper discusses thermal WTE technologies which includes incineration, gasification, pyrolysis and HTC. These four thermal technologies require mixed MSW of organic fraction to produce energy. Therefore, depending on the organic fraction of waste in Oman that is $71.20 \%$ and $65.80 \%$ of the total MSW in winter and summer respectively, and average energy content of $10 \mathrm{MJ} / \mathrm{kg}$ of MSW, it can be seen that Oman has the potential to set up WTE technology for energy recovery. 
HTC has higher future potential when compared with incineration, as it only produces toxic gases whereas incineration along with toxic gases produce ash discharge, out of which the non-usable ash has to be sent to landfills which increases the cost. Also, the energy efficiency of HTC is greater than incineration, hence, making HTC an optimum choice for Oman.

The aim of this paper was to highlight the specific aspects of WTE technologies and waste quality and quantity of Oman. Then based on the condition of waste in Oman an optimum choice of hydrothermal carbonization was proposed.

\section{Acknowledgment}

The authors are acknowledging the corporation of Environmental Services Holding Company (Be'ah) for providing required information to conduct this research.

\section{References}

A.S. Khan (2011), "Feasibility of waste-to-energy recovery technologies in Lahore, Pakistan", M.S., Norwegian University of Life Sciences, .

A. Bosmans, I. Vanderreydt, D. Geysen, and L. Helsen(2013), "The crucial role of waste-to-energy technologies in enhanced landfill mining: A technology review", Journal of Cleaner Production, vol 55, pp. 10-23,

A.J. Marshall (2013), "Commercial application of pyrolysis technology in agriculture",.

B. Basak (2016), "Pyrolysis: A sustainable way from waste to energy" .

Be'ah (2016), "Transformation of waste management in Oman", .

C. He, A. Giannis, and J.Y. Wang(2013), "Conversion of sewage sludge to clean solid fuel using hydrothermal carbonization: Hydrochar fuel characteristics and combustion behavior", Applied Energy, vol. 111, pp. 257266, .

C. Tatarniuk(2007), "The feasibility of waste-to-energy in Saskatchewan based on waste composition and quantity", M.S., University of Saskatchewan, .

C. Ducharme(2010), "Technical and economic analysis of plasma-assisted waste-to-energy processes", M.S., Columbia University, .

D.O. Onyango, and J.W. Kaluli(2016), "Pyrolysis: An alternative technology for municipal solid waste management",

D. Wong, and S. Tam(2014), "Thermal waste treatment in the European Union", .

European Commission(2006), "Integrated pollution prevent and control: reference document on the best available techniques for waste incineration", .

Fichtner Consulting Engineers Ltd(2004), "The variability of advanced thermal treatment of MSW in the UK”, ESTET, London, .

F. Ni, and M. Chen(2014), "Studies on pyrolysis and gasification of automobile shredder residue in china", Waste Management \& Research, vol. 32, issue 10, pp. 980-987, .

Gasification Technologies Council (GTC) (2011), "Gasification: The waste and energy solution", .

H. Chiu et al.(2016), "Electricity production from municipal solid waste using microbial fuel cells", Waste Management \& Research, vol. 34, issue 7, pp. 619-629,.

H. Raclavska, A. Corsaro, A. Hlavsova, D. Juchelkova, and O. Zajonc(2016), "The effect of moisture on the release and enrichment of heavy metals during pyrolysis of municipal solid waste", Waste Management \& Research, vol. 33, issue 3, pp. 267-274, .

Ithraa (2014), "Briefing from Oman waste management", 2016.
International Renewable Energy Agency (IRENA), "Sultanate of Oman renewables readiness assessment", I. Velghe, R. Carleer, J. Yperman, and S. Schreurs(2011), "Study of the pyrolysis of municipal solid waste for the production of valuable products", Journal of Analytical and Applied Pyrolysis, vol. 92, issue 2, pp. 366-375,.

J. Libra et al.(2011), "Hydrothermal carbonization of biomass residuals: A comparative review of the chemistry, processes and applications of wet and dry pyrolysis", Biofuels, vol. 2, issue 1, pp. 89-124,

J. Nixon, P. Dey, S. Ghosh, and P. Davies(2013), "Evaluation of options for energy recovery from municipal solid waste in India using the hierarchical analytical network process", Energy, vol. 59, pp. 215-223,

K. Warren et al.(2013), "Waste to energy background paper", 2013.

M.F.M. Abushammala et al.(2016), "Economic and environmental benefits of landfill gas utilisation in Oman", Waste Management and Research, vol. 34, issue 8, pp. 717-723,

M. Samah, L. Manaf, A. Aris, and W. Sulaiman(2011), "Solid waste management: Analytical hierarchy process (AHP) application of selecting treatment technology in Sepang Municipal Council, Malaysia", Curr World Environ, vol. 6, pp. 1-16,.

M. Ouadi, J. Brammer, M. Kay, and A. Hornung(2013), "Fixed bed downdraft gasification of paper industry wastes", Applied Energy, vol. 103, pp. 692-699,.

N. Berge, L. Li, J. Flora, and K. Ro(2015), "Assessing the environmental impacts of energy production from hydrochar generated via hydrothermal carbonization of food waste", Waste Management and Research, vol. 43, pp. 203-217,.

National Research Council, "Waste incineration overview", in Waste incineration and public health, Washington, D.C.: National Academy Press, 2000, p. 364.

R. Atwadkar, L. Jafhav, M. Wagh, and N. Shinde(2014), "A multi criteria ranking of different technologies for the waste to energy of municipal solid waste in the city of Kolhapur", International Journal of Emerging Technology and Advanced Engineering, vol. 4, issue 7, pp. 2250-2459,

Ricardo Energy \& Environment, "Thermal treatment", 2016.

S. Zafar(2016), "Solid waste management in Oman", EcoMENA,. [Online]. Available: http://www.ecomena.org/solid-waste-oman/. [Accessed: 31- March- 2017].

S. Narnaware, N. Srivastava, and S. Vahora(2016), "Gasification: An alternative solution for energy recovery and utilization of vegetable market waste", Waste Management and Research, vol. 35, issue 3, pp. 276-284,.

Stantec(2011), "Waste to Energy: A technical review of municipal solid waste thermal treatment practices".

T. Palanivel, and H. Sulaiman(2014), "Generation and composition of municipal solid waste (MSW) in Muscat, Sultanate of Oman", in International Conference on Environmental Science and Development (ICESD), Singapore, pp. 96-102.

U. Arena(2012), "Process and technological aspects of municipal solid waste gasification. A review", Waste Management, vol. 32, issue 4, pp. 625-639,.

W. Caruso, D. Sorenson, and A. Mossa(2016), "Alternative energy technologies: high tech solution for urban carbon reduction",.

X. Lu(2014), "Understanding hydrothermal carbonization of mixed feedstocks for waste conversion", Ph.D, University of South Carolina,. 